\title{
Trend analysis of weather parameters over Indian Sundarbans
}

\section{UTTAM KUMAR MANDAL*，DIBYENDU BIKAS NAYAK, SOURAV MULLICK, ARPAN SAMUI, AMIT KUMAR JANA, K.K. MAHANTA, SHISHIR RAUT, SHIVAJI ROY and D. BURMAN}

\author{
ICAR-Central Soil Salinity Research Institute, Regional Research Station, \\ Canning Town, West Bengal-743329, India \\ *Corresponding author:uttam_icar@yahoo.com
}

\begin{abstract}
Sundarbans in West Bengal of India by virtue of its strategic location in the Eastern coast on the Bay of Bengal falls in one of the most vulnerable zones of abrupt climate change. Temporal trends of weather parameters of Canning Town (22 $18^{\prime} 10.8^{\prime \prime}$ N Latitude, $88^{\circ} 39^{\prime} 58.4^{\prime \prime}$ E Longitude, elevation $3.52 \mathrm{~m}$ $\mathrm{msl}$ ) representing Indian Sundarbans were analysed by non-parametric Mann-Kendall test and Sen's slope approaches. Analysis of long term rainfall data (1966-2015) indicated that Canning receives a mean annual rainfall of $1821 \mathrm{~mm}( \pm 341.8 \mathrm{~mm})$ with a considerable variation $(\mathrm{CV}=18.8 \%)$. The results revealed that total annual rainfall trend decreased non-significantly at the rate of $0.94 \mathrm{~mm} \mathrm{yr}^{-1}$. On an average 84.4 rainy days in a year was recorded in the region, whereas during last ten years (2006-2015), the number of rainy days was reduced to 79.7 days $\mathrm{yr}^{-1}$. There was no significant change in maximum, minimum and mean temperature of the region. Bright sunshine hours declined significantly at an annual rate of $0.055 \mathrm{hr}$ $\mathrm{yr}^{-1}$. Reference crop evapotranspiration $\left(\mathrm{ET}_{0}\right)$ calculated using FAO Penman-Monteith method revealed that annual $\mathrm{ET}_{0}$ significantly decreased at the rate of $5.98 \mathrm{~mm} \mathrm{yr}^{-1}$. There was 2.7 times surplus rainfall than crop evapotranspiration during monsoon months indicating very high scope of water harvesting to tackle water logging during the monsoon season and unavailability of fresh water for irrigation during lean season.
\end{abstract}

Key words: Coastal region, climate change, trend analysis, Mann-Kendall test, Canning

Climate change impacts are being witnessed all over the world but the country like India is more vulnerable in view of its huge population, excessive pressure on natural resources and relatively weak coping mechanism. Expected effects of changes in global climate include warmer temperatures, rising sea levels, and potentially more frequent and extreme weather events such as hurricanes, tropical cyclones and heat waves. The Sundarbans located in the southern part of West Bengal, India and Bangladesh lies on the delta of Ganges, Brahmaputra and Meghna rivers in the Bay of Bengal falls in one of the most vulnerable zones of abrupt climate change (Mandal et al., 2019a). The Indian Sundarbans are located in the districts of North and South 24 Parganas representing the coastal part of West Bengal. The World Heritage Site is under constant threat of powerful nor'westers, bay cyclones, tidal surges and constant change of courses by the numerous distributaries in the active part of the delta. Knowing the trend of long-term weather variables responsible for the climate of the islands holds importance for adaptation and mitigation strategies to sustain food production in this islands ecosystem.
Climate change projections made for India indicate an overall increase in temperature by $1-4^{\circ} \mathrm{C}$ and change in precipitation by $9-16 \%$ toward 2050s (Krishna Kumar et al., 2011). Another significant aspect of climate change is the increase in the frequency of occurrence of extreme events such as droughts, floods, and cyclones. All of these expected changes will have adverse impacts on climate sensitive sectors such as agriculture, forest, and coastal ecosystems and also on availability of water for different uses and on human health.

The impact of climate change is quite severe for the coastal areas because of proximity to sea. IPCC has projected that with the rise in temperature and subsequent rise in sea level in the coasts of Asia, including the Indian Sundarbans will be exposed to increasing risks like coastal erosion (IPCC, 2007). WWF- INDIA has projected rising trend in surface temperature $\left.\left(0.019^{\circ} \mathrm{C}^{-1}\right)^{-1}\right)$ for the Sundarbans region and predicted that more than 1.3 million people will be affected by the sea-level rise and permanent submergence of land masses, storm surges and coastal erosions (WWF-India, 2010). The coastal impact in the region is very large because of the low, 
flat coastal terrain, high density of population, low awareness of community, inadequate response and preparedness and absence of hedging mechanism. Though the region receives very high rainfalls, which are concentrated only over a few monsoon months, most of the rainwater goes waste as runoff into sea and also creates widespread water logging of the lowlying agricultural fields. A comprehensive knowledge of climate fluctuations and corresponding adaptation strategies through rainwater harvesting is crucial for the progress towards sustainability.

Since rainfed agriculture dominates the food grain production chain of the region, any abrupt change in climate variables, particularly rainfall patterns poses a serious threat to food and environmental security of the entire region. Aside few sporadic findings about climate change and its possible impacts in Sundarbans region mostly based on only rainfall and to a lesser extent temperatures, the region is less explored and very little is known, making the future climate change scenarios more uncertain for devising any conclusive mitigation and adaptation measures. Most of the trend analysis study in weather data of the region carried out considering weather data of less than 30 years. Non-availability of authentic and homogenous long time baseline data on weather variables at temporal and spatial scale is another bottleneck in assessing real time climate change implications. Lack of information on the implications of other potential climate change variables (e.g. sunshine duration, relative humidity, wind speed, evapotranspiration etc.) has further compounded the problem of impact assessment. Knowledge of the duration of sunshine of any location is vital since it directly influences mass and energy balances, macro and micro-climates, biomass production and thus, radiation sensitive climate variables like atmospheric evaporative demand, temperature, rainfall etc. are very crucial.

Although several researchers have explored the island in the context of coastal erosion, cyclone, tidal ingression, sealevel rise, etc. there is no comprehensive study on long-term behaviour of climate variables responsible for climate change in the island. Realizing the need to detect the direction of change (+/-) in climate variables and also to quantify the magnitude of such changes (if any), in the present study, we have analysed long-term (1966-2015) climate variables (namely rainfall, temperature, relative humidity, sunshine duration, evaporation, rainy days and wind speed) using nonparametric Mann- Kendall test. The magnitudes of the trends in climate variables were estimated using Sen's slope.

\section{MATERIALS AND METHODS}

Climatic data for 50 years (1966-2015) was collected from the agro-meteorological observatory located at ICARCentral Soil Salinity Research Institute, Regional Research Station, Canning Town (22 $18^{\prime} 10.8^{\prime \prime}$ N Latitude, 88 39'58.4" E Longitude, elevation $3.52 \mathrm{~m} \mathrm{msl}$ ) in Indian Sundarbans. The climate of Sundarbans is hot and humid which influenced in a major way by the southwest monsoon occurring during June to September. For trend analysis of climatic variables, daily weather data for rainfall, maximum and minimum temperature, relative humidity $(0730 \mathrm{hr}$ and $1430 \mathrm{hr})$, wind speed and sunshine hours were used for the study. The reference evapotranspiration $\left(\mathrm{ET}_{0}\right)\left(\mathrm{mm} \mathrm{day}^{-1}\right)$ was determined using the FAO Penman-Monteith equation (Allen et al., 1998).

To study intra-annual variations of climatic data, the year was divided into three different seasons: pre-monsoon (March-May), monsoon (June-September) and post-monsoon (October-February) months. Extreme rainfall events were considered when rainfall of more than $100 \mathrm{~mm}$ occurred in a single day (24 hour). Monsoon rainfall was classified as deficient when the actual rainfall was less than the difference between long period average (LPA) and its coefficient of variation (LPA-CV), normal when actual rainfall was within $\mathrm{LPA} \pm \mathrm{CV}$ and excess when actual rainfall was more than LPA $+\mathrm{CV}$ of the corresponding year (Narjary et al., 2014). Meteorological drought years were considered based on number of consecutive weeks (CW) in a year with rainfall less than the water requirements of rice crop during various growth stages i.e. $55 \mathrm{~mm}$. The degree of severity was assessed in terms of low $(2 \mathrm{CWs})$, moderate $(3 \mathrm{CWs})$, severe $(4 \mathrm{CWs})$ and very severe (>4CWs) (Choudhury et al., 2012).

A non-parametric Mann-Kendall (MK) test was used for identifying trends in the time -series data. A nonparametric test is taken into consideration over the parametric one since meteorological parameters like rainfall is usually positively (generally) or negatively skewed data with some extreme values and not normally distributed. The MK test is used to check the null hypothesis of no trend versus the alternative hypothesis of the existence of an increasing or decreasing trend. A high positive value of the MK statistic $\tau$ (tau), is an indicator of an increasing trend, and a low negative value indicates a decreasing trend and $\tau$, is assumed to be 0 , i.e., no trend. The $\mathrm{p}$-value for the MK test indicates the absence or presence of any statistically significant trends. If the computed value of $\mathrm{p}>\mathrm{p}_{\alpha}$ the null hypothesis (Ho) is rejected at 
Table 1: Trend analysis of long-period rainfall distribution and rainy days at Canning Town of Sundarbans region during 1966-2015

\begin{tabular}{|c|c|c|c|c|c|c|}
\hline $\begin{array}{l}\text { Rainfall } \\
(\mathrm{mm})\end{array}$ & Total annual & $\begin{array}{r}\text { Pre-monsoon } \\
(\mathrm{MAM})\end{array}$ & $\begin{array}{r}\text { Monsoon } \\
\text { (JJAS) }\end{array}$ & $\begin{array}{r}\text { Post-monsoon } \\
\text { (ONDJF) }\end{array}$ & Rainy days & Extreme rain \\
\hline Minimum & $1030.8(1970)$ & 12 & 803.6 & 34.3 & 59 & 0 \\
\hline Maximum & $2461.3(1979)$ & 663.9 & 2070.1 & 604.2 & 105 & 4 \\
\hline Mean & 1821.2 & 239.4 & 1355.0 & 226.8 & 84.4 & 1.4 \\
\hline $\mathrm{CV}(\%)$ & 18.8 & 50.1 & 21.2 & 53.7 & 11.7 & 94.6 \\
\hline Kendall's Tau & -0.019 & 0.020 & 0.015 & -0.020 & -0.115 & 0.103 \\
\hline$P$ value & 0.857 & 0.844 & 0.884 & 0.844 & 0.255 & 0.343 \\
\hline
\end{tabular}

Pre-monsoon: MAM, March, April, May; Monsoon: JJAS, June, July, August, September; Post-monsoon: ONDJF, October, November, December, January, February. Values in parentheses are the year when maximum and minimum rainfall recorded. CV, Coefficient of variation.

$\alpha$ level of significance in a two-sided test. In this analysis, the null hypothesis was tested at $95 \%$ confidence level. The magnitude of the trend is predicted by the Sen's estimator (Sen, 1968). Positive value of the estimator indicates an upward or increasing trend and a negative value gives a downward or decreasing trend in the time series.

\section{RESULTS AND DISCUSSION}

\section{Rainfall distribution pattern}

Long-term analysis of rainfall data (1966-2015) (Table 1) indicated that Canning receives a mean annual rainfall of $1821 \mathrm{~mm}$ with a considerable variation $(\mathrm{CV}, 18.8 \%)$ in total amount from as low as $1031 \mathrm{~mm}(-43.4 \%)$ during 1970 to as high as $2461 \mathrm{~mm}(+35.1 \%)$ during 1979 . Out of 50 years rainfall data, 36 years received normal (within $\mathrm{LPA} \pm \mathrm{CV}$ ), 6 years received deficit $(25-43 \%)$ and 8 years received excess rainfall (19-35\%). Mann-Kendall test affirmed non-linear $(\mathrm{r}=0.044)$, non-significant annual marginal decreasing trend of total rainfall (tau value -0.02 ) at the rate $0.94 \mathrm{~mm}_{\text {year }}{ }^{-1}$. The decreasing trend in annual and monsoon rainfall during 19012013 was observed in most of the districts of the Odisha state (Prabhakar et al., 2018), on the other hand in coastal Karnataka there was no change in rainfall pattern and its seasonal distribution over time (Hanumanthappa et al., 2010). Earlier Mandal et al. (2013) indicated a decreasing rainfall trend of $5.79 \mathrm{~mm} \mathrm{yr}^{-1}$ during 1982-2010 in Sagar Island of Sundarbans, whereas WWF-India (2010) recorded increasing trend between 1990 to 2000 . But in both the cases the database used for trend analysis was less than 30 years. Non-availability of authentic and homogenous long time baseline data on weather variables at temporal and spatial scale is another bottleneck in assessing real time climate change implications. However, the information on variability and trends of precipitation over a region is always useful in the agricultural production management of that region (Yang et al., 2019).

Mean (of 50 years) monthly rainfall varied considerably and July received the highest (381.6 $\pm 140.4 \mathrm{~mm})$, whereas December received the lowest $(9.2 \pm 23.7 \mathrm{~mm})$ amount of rainfall. Monsoon months (June-September) received higher monthly rainfall (298.1-381.6 mm) which contributed $52.7-89.4 \%$ of the total annual rainfall. The variability $(\mathrm{CV}, 21.2 \%)$ during monsoon rainfall was relatively less compared to pre $(\mathrm{CV}, 50.1 \%)$ and post $(53.7 \%)$ monsoon rainfall. In last fifty years, the highest monthly rainfall of $838.4 \mathrm{~mm}$ was received in 28 rainy days of the month of July in 2015. Trend analysis exhibited a nonsignificant increasing trend of monthly rainfall during April, May, July, September and October whereas there was decreasing trend in the month of February, March, June, August and November. The mean annual rainfall in 23 nonconsecutive years deviated negatively (-0.15 - 43.4\%) indicating rainfall below LPA, whereas in the remaining 27 years it deviated positively $(0.05-35.15 \%)$ exhibiting rainfall above LPA.

Monsoon months (June-September, JJAS) contributed $74.4 \%(1355.01 \mathrm{~mm})$ with an average variability of $21.2 \%$ to the annual rainfall, whereas pre-monsoon (March-May, 


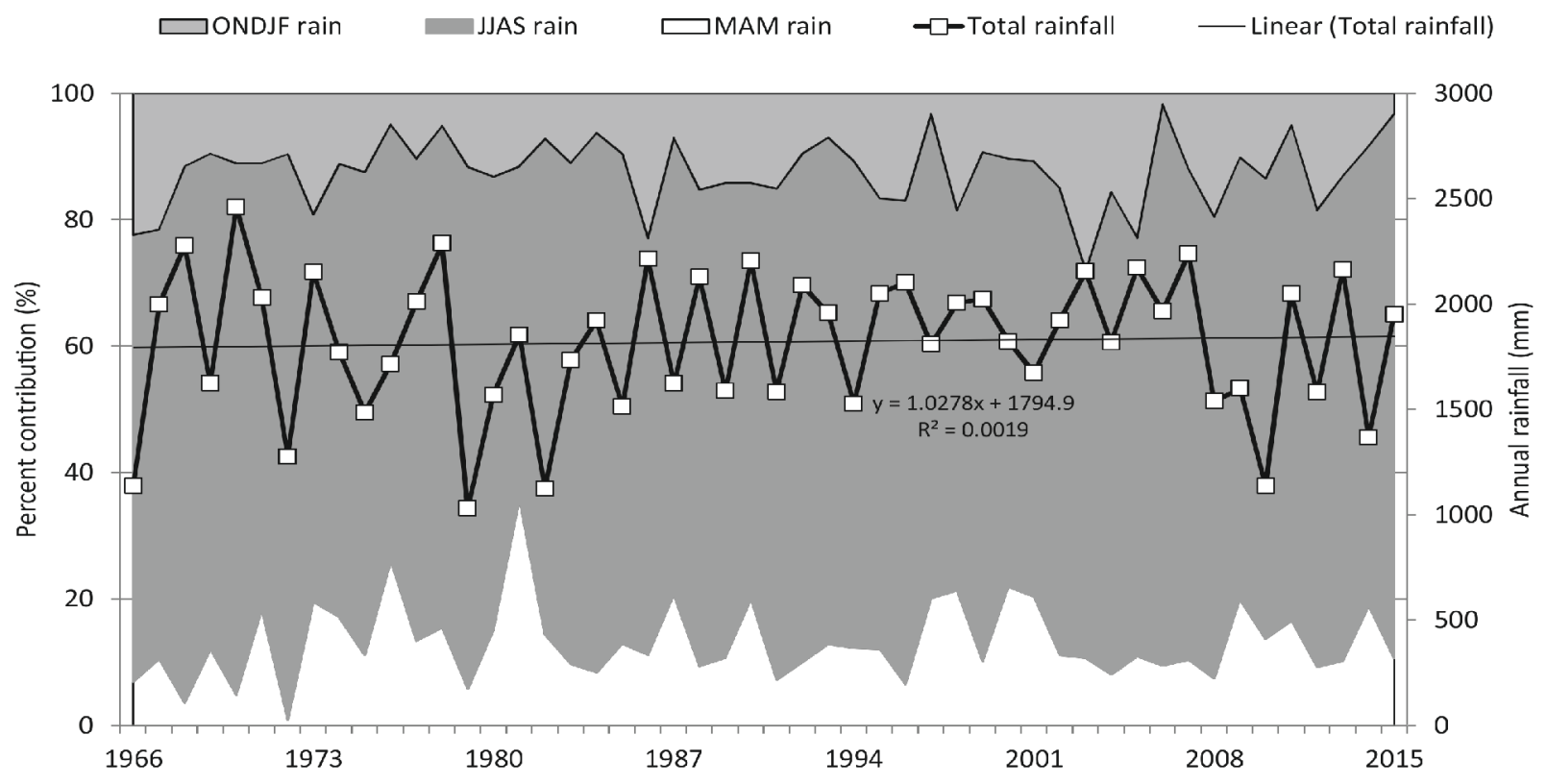

Fig. 1: Temporal variation of long period (1966-2015) annual and seasonal rainfall distribution at Canning Town of Sundarbans region. MAM, March, April, May; JJAS, June, July, August, September; ONDJF, October, November, December, January, February.

MAM) and post-monsoon (October-February, ONDJF) months contributed $13.1 \%$ and $12.5 \%$ of annual rainfall with a $\mathrm{CV}$ of $50.1 \%$ and $53.7 \%$, respectively (Table 1, Fig. 1). Monsoon and pre-monsoon seasons' rainfall showed a nonsignificant increasing trend @ 0.407 and $0.337 \mathrm{~mm} \mathrm{yr}^{-1}$ but the post-monsoon months showed a decreasing trend @ -0.288 mmyr $r^{-1}$.

Annual rainy days (rainfall $>2.5 \mathrm{~mm}$ in a day) varied widely from 59 (in 1972) to as high as 105 (in 1990) with LPA of 50 years of $84.4 \pm 9.84$ days (Table 1). The pre-monsoon, monsoon and post-monsoon months had an average of 12.04 , 61.82 and 10.5 rainy days, respectively. Nearly $27 \%$ of the rainy days were in pre- and post-monsoon months with a wide variability $(\mathrm{CV},>37 \%)$ compared to relatively non consistent pattern $(\mathrm{CV}, 10.5 \%)$ with $73 \%$ contribution to annual rainy days by monsoon months. Monthly average rainy days during pre-monsoon, monsoon and post-monsoon months were $\sim 4.01, \sim 15.45$, and $\sim 2.1$, respectively. Trend analysis of annual rainy days showed a non-significant declining rate @ - -0.119 days $\mathrm{yr}^{-1}$.

Observation of extreme rainfall events indicated that Canning received a total of 70 such events when rainfall received in a single day $\left(\mathrm{RX}_{\text {lday }}\right)$ was $>100 \mathrm{~mm}$ of which 48 times 1 -day maximum rainfall was less than $150 \mathrm{~mm}$ and for the remaining 22 times it was higher than $150 \mathrm{~mm}\left(\mathrm{RX}_{\text {Iday }}>150\right.$ $\mathrm{mm}$ ). Maximum rainfall recorded in a single day was 266.5 $\mathrm{mm}$ on $5^{\text {th }}$ June 1984 . Seasonal distribution pattern of 1-day extreme rainfall events $\left(\operatorname{RX}_{\text {lday }}>100 \mathrm{~mm}\right)$ was highest during monsoon months (54 times) whereas pre- and post- monsoon months experienced 4 and 12 times, respectively.

To understand the decadal behaviour of rainfall and rainy days, means of 50 years rainfall and rainy days were calculated and compared with the decadal means. It was observed during the last 10 years (2006-2015) that total rainfall reduced by $61.3 \mathrm{~mm}$ from average rainfall of $1821 \mathrm{~mm}$ and number of rainy days decreased by 4.7 days from the average number of rainy days of 84.4 (Fig. 2a). The Indian Institute of Tropical Meteorology (IITM) with different IPCC scenarios projected that the number of rainy days may decrease by $20-30 \%$ which implies that the intensity of rainfall is likely to increase country wise (Nakicenovic et al., 2000). To understand the epochal behaviour of rainfall series for different monsoon months, 50 years running means of each of the monsoon month was calculated and decadal means of each of the monsoon month was compared (Fig. 2b). It was observed that in the recent decade (2001-2010) epochal behaviour of June and August rainfall had reduced whereas July and September rainfall had increased. In the last 10 years (2006-2015) there was increase in August and September rainfall whereas June and July rainfall decreased. 
Table 2: Statistical analysis of annual march of temperature trends at Canning Town (1966-2015)

\begin{tabular}{|c|c|c|c|c|c|c|c|c|c|}
\hline \multirow{2}{*}{$\begin{array}{l}\text { Paramet } \\
\text { ers }\end{array}$} & \multirow[b]{2}{*}{$\begin{array}{l}\text { Maximum } \\
\text { Temp. }\left({ }^{\circ} \mathrm{C}\right)\end{array}$} & \multirow[b]{2}{*}{$\begin{array}{l}\text { Minimum } \\
\text { Temp. }\left({ }^{\circ} \mathrm{C}\right)\end{array}$} & \multicolumn{3}{|c|}{ Summer (Apr-Oct.) } & \multicolumn{4}{|c|}{ Winter (Nov-Mar) } \\
\hline & & & $\begin{array}{r}\text { Mean } \\
\text { Temp. }\left({ }^{0} \mathrm{C}\right)\end{array}$ & $\begin{array}{l}\text { Minimum } \\
\text { Temp. }\left({ }^{0} \mathrm{C}\right)\end{array}$ & $\begin{array}{l}\text { Maximum } \\
\text { Temp. }\left({ }^{0} \mathrm{C}\right)\end{array}$ & $\begin{array}{r}\text { Mean } \\
\text { Temp. }\left({ }^{0} \mathrm{C}\right)\end{array}$ & $\begin{array}{l}\text { Minimum } \\
\text { Temp. }\left({ }^{0} \mathrm{C}\right)\end{array}$ & $\begin{array}{l}\text { Maximum } \\
\text { Temp. }\left({ }^{0} \mathrm{C}\right)\end{array}$ & $\begin{array}{r}\text { Mean } \\
\text { Temp. }\left({ }^{\circ} \mathrm{C}\right)\end{array}$ \\
\hline Minimum & 30.15 & 20.73 & 25.69 & 24.22 & 31.67 & 28.17 & 15.85 & 27.46 & 22.00 \\
\hline Maximum & 31.52 & 22.98 & 27.07 & 26.24 & 33.41 & 29.79 & 18.54 & 29.57 & 23.46 \\
\hline Mean & 30.85 & 21.88 & 26.38 & 25.41 & 32.61 & 29.05 & 16.93 & 28.39 & 22.68 \\
\hline $\mathrm{CV} \%$ & 1.03 & 2.06 & 1.17 & 1.69 & 1.28 & 1.30 & 3.50 & 1.74 & 1.88 \\
\hline $\begin{array}{l}\text { Kendall } \\
\text { 's Tau }\end{array}$ & 0.092 & 0.121 & 0.105 & $0.276^{* *}$ & $0.236^{*}$ & $0.307 * *$ & -0.063 & -0.110 & -0.163 \\
\hline P-value & 0.94 & 0.23 & 0.52 & 0.006 & 0.027 & 0.004 & 0.531 & 0.307 & 0.127 \\
\hline $\begin{array}{l}\text { Sen's } \\
\text { Slope }\end{array}$ & 0.005 & 0.005 & 0.004 & 0.011 & 0.012 & 0.012 & -0.003 & -0.008 & -0.009 \\
\hline
\end{tabular}
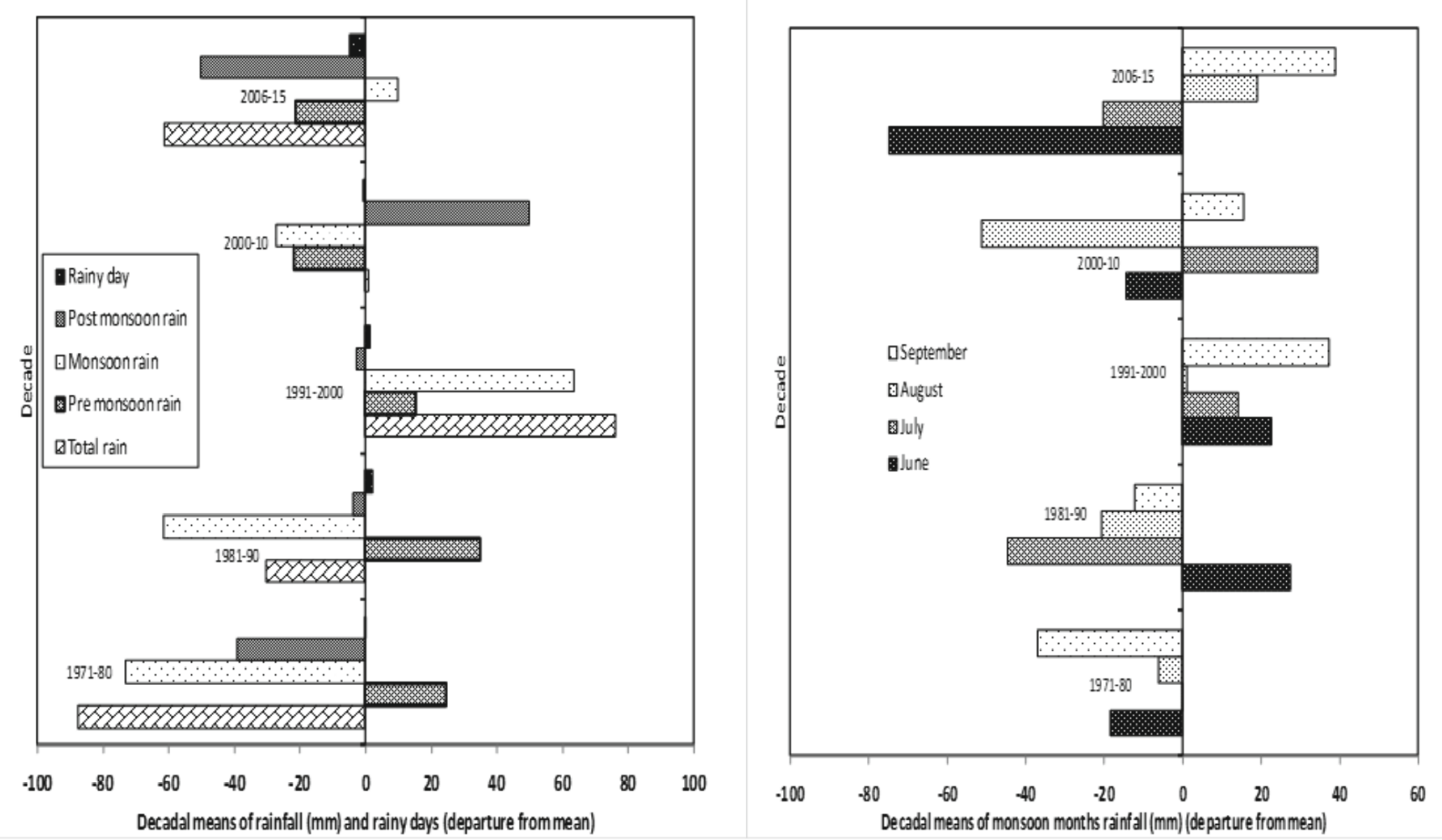

Fig. 2: Decadal means of rainfall (mm), rainy days (a) and means of monsoon months rainfall ( $\mathrm{mm}$ ) (b) departure from mean

\section{Air temperature}

Maximum monthly surface temperature varied from 30.15 to $31.52^{\circ} \mathrm{C}$ with long term average of $30.85 \pm 0.32^{\circ} \mathrm{C}$ (Table 2). Similarly minimum monthly surface temperature varied from 20.73 to $22.98^{\circ} \mathrm{C}$ with a mean of $21.88 \pm 0.45^{\circ} \mathrm{C}$. Average monthly temperature was highest during May $\left(30.34^{\circ} \mathrm{C}\right)$ and lowest in January $\left(19.15^{\circ} \mathrm{C}\right)($ Table 3$)$. The mean maximum air temperature during summer (AMJJASO, April,
May, June, July, August, September and October) ranges from 31.67 to $33.41^{\circ} \mathrm{C}$. The mean minimum temperature during winter (NDJFM, November, December, January, February and March) ranges from 15.85 to $18.54^{\circ} \mathrm{C}$. The highest monthly maximum temperature experienced by the island region was $37.27^{\circ} \mathrm{C}$ (May 1979) and the lowest monthly minimum temperature was $10.82^{\circ} \mathrm{C}$ during January 1997 . Mann-Kendall trend statistics revealed a non-significant rising trend in monthly minimum ( $\mathrm{Tau}=0.121$, Sen's slope 0.005$)$, 
Table 3: Mann-Kendall trend statistics of monthly temperature $\left({ }^{\circ} \mathrm{C}\right)$ at Canning Town of Sundarbans region during $1966-2015$

\begin{tabular}{|c|c|c|c|c|c|c|c|c|c|c|c|c|}
\hline $\begin{array}{l}\text { parame } \\
\text { ters }\end{array}$ & Jan. & Feb. & Mar. & Apr. & May & June & July & Aug & Sep. & Oct. & Nov. & Dec. \\
\hline \multicolumn{13}{|c|}{ Minimum temperature $\left({ }^{0} \mathrm{C}\right)$} \\
\hline Lowest & 10.82 & 14.09 & 18.08 & 20.75 & 24.13 & 23.64 & 18.81 & 22.11 & 24.63 & 22.19 & 16.56 & 12.00 \\
\hline Highest & 15.17 & 18.58 & 23.90 & 28.15 & 30.00 & 27.58 & 27.19 & 26.83 & 26.63 & 25.40 & 22.04 & 22.34 \\
\hline Mean & 13.18 & 16.64 & 21.34 & 24.66 & 25.80 & 26.18 & 25.80 & 25.87 & 25.70 & 23.98 & 19.17 & 14.34 \\
\hline $\mathrm{CV} \%$ & 8.23 & 6.17 & 5.34 & 4.62 & 3.89 & 2.67 & 4.44 & 3.23 & 1.68 & 2.86 & 6.46 & 10.43 \\
\hline $\begin{array}{l}\text { Kendall } \\
\text { 's Tau }\end{array}$ & $-0.221^{*}$ & -0.032 & 0.027 & 0.090 & 0.111 & $0.194^{*}$ & $0.220^{*}$ & $0.274^{* *}$ & 0.192 & 0.031 & 0.039 & -0.005 \\
\hline$P$ value & 0.025 & 0.751 & 0.790 & 0.367 & 0.268 & 0.050 & 0.026 & 0.005 & 0.052 & 0.763 & 0.700 & 0.966 \\
\hline $\begin{array}{l}\text { Sen's } \\
\text { Slope }\end{array}$ & -0.026 & -0.004 & 0.003 & 0.008 & 0.012 & 0.014 & 0.012 & 0.014 & 0.009 & 0.003 & 0.004 & -0.001 \\
\hline \multicolumn{13}{|c|}{ Maximum temperature $\left({ }^{0} \mathrm{C}\right)$} \\
\hline Lowest & 23.18 & 25.82 & 29.30 & 31.63 & 32.54 & 31.11 & 29.98 & 29.88 & 30.37 & 30.03 & 27.69 & 24.29 \\
\hline Highest & 27.87 & 31.94 & 34.82 & 36.70 & 37.27 & 35.45 & 33.05 & 32.69 & 32.57 & 32.51 & 31.74 & 27.63 \\
\hline Mean & 25.15 & 28.47 & 32.90 & 34.81 & 34.77 & 33.19 & 31.52 & 31.29 & 31.41 & 31.20 & 29.32 & 26.17 \\
\hline $\mathrm{CV} \%$ & 4.04 & 4.31 & 3.48 & 3.33 & 2.84 & 3.05 & 2.14 & 2.04 & 1.70 & 2.08 & 2.58 & 2.74 \\
\hline $\begin{array}{l}\text { Kendall } \\
\text { 's Tau }\end{array}$ & $-0.245^{*}$ & 0.000 & -0.075 & -0.117 & 0.151 & 0.044 & 0.121 & $0.455^{* *}$ & $0.227^{*}$ & 0.063 & 0.043 & $-0.20 *$ \\
\hline$P$ value & 0.013 & 0.993 & 0.455 & 0.239 & 0.128 & 0.662 & 0.226 & $<0.001$ & 0.022 & 0.531 & 0.674 & 0.044 \\
\hline $\begin{array}{l}\text { Sen’s } \\
\text { Slope }\end{array}$ & -0.026 & 0.000 & -0.008 & -0.013 & 0.017 & 0.005 & 0.008 & 0.030 & 0.013 & 0.004 & 0.003 & -0.016 \\
\hline \multicolumn{13}{|c|}{$\overline{\text { Mean temperature }\left({ }^{0} \mathrm{C}\right)}$} \\
\hline Lowest & 17.32 & 20.19 & 24.21 & 26.91 & 28.36 & 27.92 & 27.38 & 26.41 & 22.75 & 26.19 & 22.74 & 19.21 \\
\hline Highest & 21.20 & 25.02 & 29.30 & 31.70 & 33.00 & 31.38 & 30.10 & 29.59 & 29.42 & 28.88 & 26.88 & 21.89 \\
\hline Mean & 19.15 & 22.59 & 27.12 & 29.76 & 30.34 & 29.70 & 28.73 & 28.64 & 28.42 & 27.57 & 24.27 & 20.24 \\
\hline $\mathrm{CV} \%$ & 4.79 & 4.37 & 3.92 & 3.13 & 3.05 & 2.60 & 1.83 & 1.99 & 3.43 & 1.97 & 3.55 & 3.31 \\
\hline $\begin{array}{l}\text { Kendall } \\
\text { 's Tau }\end{array}$ & $-0.224^{*}$ & -0.010 & -0.003 & -0.005 & 0.068 & 0.070 & $0.299 * *$ & $0.414^{* *}$ & 0.303 & 0.087 & 0.076 & -0.138 \\
\hline $\mathrm{P}$ value & 0.024 & 0.925 & 0.979 & 0.966 & 0.498 & 0.487 & 0.002 & $<0.0001$ & 0.002 & 0.386 & 0.448 & 0.166 \\
\hline $\begin{array}{l}\text { Sen's } \\
\text { Slope }\end{array}$ & -0.022 & -0.001 & 0.000 & -0.001 & 0.006 & 0.006 & 0.011 & 0.024 & 0.018 & 0.005 & 0.006 & -0.011 \\
\hline
\end{tabular}

* Significant at $\mathrm{p} \leq 0.05, * *$ Significant at $\mathrm{p} \leq 0.01$ 
Table 4: Trend analysis of mean annual relative humidity, wind speed, sunshine hour (SSH) and reference evapotranspiration (ET $\left.{ }_{0}\right)$

\begin{tabular}{lrrccr}
\hline parameters & $\begin{array}{r}\text { Relative } \\
\text { humidity } \\
(\mathrm{RH} 730 \mathrm{hr}) \\
(\%)\end{array}$ & $\begin{array}{r}\text { Relative } \\
\text { Humidity } \\
(\mathrm{RH} 1430 \mathrm{hr})\end{array}$ & $\begin{array}{r}\text { Wind speed } \\
(\%)\end{array}$ & $\begin{array}{r}\text { Sun shine hour per day } \\
(1976-2015)\end{array}$ & $\begin{array}{r}\text { Annual total Reference } \\
\text { evapotranspiration } \\
\left(\mathrm{ET}_{0}\right)\left(\begin{array}{r}(1967-2015) \\
(\mathrm{mm})\end{array}\right.\end{array}$ \\
\hline Minimum & 76.01 & 53.68 & 5.12 & 7.14 & 1276.9 \\
Maximum & 92.78 & 69.12 & 8.28 & 10.10 & 1740.00 \\
Mean & 87.18 & 60.41 & 6.48 & 8.64 & 1448.38 \\
CV(\%) & 4.36 & 6.11 & 13.03 & 7.77 & 7.88 \\
Kendall' Tau & 0.10 & 0.17 & $-0.65^{* *}$ & $-0.800^{* *}$ & $-0.500^{* *}$ \\
P value & 0.35 & 0.09 & $<0.0001$ & $<0.0001$ & $<0.0001$ \\
Sens's Slope & 0.04 & 0.06 & -0.06 & -0.055 & -5.98 \\
\hline
\end{tabular}

monthly maximum ( Tau $=0.092$, Sen's slope 0.005$)$ and mean temperature $(\mathrm{Tau}=0.105$, Sen's slope 0.004). Maximum temperature reflected marginal rising trend in seven months from May to November and decreasing trend during December, January, March and April, whereas minimum temperature manifested rising trend during March-November and decreasing trend during December-February. The mean monthly temperature of July and August showed significant increasing trend @ of $0.011^{\circ} \mathrm{C}$ and $0.024^{\circ} \mathrm{C}$, respectively whereas, January exhibited significant decreasing trend @ $0.022^{\circ} \mathrm{C}$ (Table 3 ). Though global warming is very prominent in other part of the world including India, its effect in coastal ecosystem is marginal.

\section{Relative humidity and wind speed}

Annual trend of maximum (morning) and minimum relative humidity (RH $730 \mathrm{Hr}$ and $\mathrm{RH} 1430 \mathrm{Hr}$ ) at Sundarbans enumerated a non-significant rise $(\mathrm{Tau}=0.10,0.17)$ at the rate of $0.04 \% 0.06 \%$, respectively (Table 4 ). In general air temperature is directly related to its water holding capacity of the atmosphere. As there was only marginal non-significant increase in temperature the relative humidity also increased marginally in the region.

Mean annual wind speed at Sundarbans varied from 5.12 to $8.28 \mathrm{~km} \mathrm{hr}^{-1}$ with a mean value of $6.48 \pm 0.84 \mathrm{~km} \mathrm{hr}^{-1}$ (Table 4). In the month of May average wind speed was maximum (11.39 $\mathrm{km} \mathrm{hr}^{-1}$ ) while minimum wind speed was recorded in the month of December $\left(2.26 \mathrm{~km} \mathrm{hr}^{-1}\right)$. Trend analysis reflected a significant Decline in aggregated mean wind speed at the rate of $0.06 \mathrm{~km} \mathrm{hr}^{-1} \mathrm{yr}^{-1}$.

\section{Sunshine duration}

Mean annual sunshine duration at Sundarbans varied from 7.14-10.10 $\mathrm{hr}_{\text {day }}{ }^{-1}$ with an average of $8.64 \pm 0.67 \mathrm{hr} \mathrm{day}^{-1}$
(Table 4). Monthly LPA of sunshine hour was highest in April $\left(8.99 \pm 0.80 \mathrm{hr}^{-1 a y}{ }^{-1}\right)$ and lowest in July $\left(4.29 \pm 1.00 \mathrm{~h} \mathrm{day}^{-1}\right)$. Mann-Kendall test confirmed an annual decreasing trend of sunshine duration throughout the year and it varied @ - 0.075 $\mathrm{hrday}^{-1}(\mathrm{Tau}=-0.643)$ during December to $-0.038 \mathrm{hr} \mathrm{day}^{-1}$ (Tau $=-0.409$ ) during February. The mean annual sunshine hours also reflected a significant declining trend $(\mathrm{Tau}=-0.800)$ at the rate of 0.055 hours or 3.3 minutes per year.

Annual evapotranspiration $\left(\mathrm{ET}_{0}\right)$ calculated based on Penman-Monteith equation reflected a significant $(\mathrm{p}<0.001)$ decreasing trend $(\mathrm{Tau}=-0.500)$ at the rate of $5.98 \mathrm{~mm} \mathrm{yr}^{-1}$ (Table 4). Pre- and post-monsoon rainfall meets the 45 and $51 \%$ of $\mathrm{ET}_{0}$, whereas there were 2.7 times surplus rainfall than $\mathrm{ET}_{0}$ during monsoon months.

Though there was no change in annual rainfall there was a decreasing trend of evapo-transpiration (Table 4) which indicated further increase in inundation of land masses both in terms of area and duration. The decrease in $\mathrm{ET}_{0}$ is associated with the decreasing trend of sunshine hours in the region. Similar observation of decreasing trend of annual sunshine duration was also made by Choudhury et al. (2012) in North East India. It is assumed that due to the dominance of overcast sky condition (cloudiness) during monsoon months, more particularly in July, sunshine duration was minimum despite having maximum day length in northern hemisphere. Also anthropogenic environment degradation activities like deforestation, fossil fuel burning, bricks burning and other infrastructural development across coastal region are resulting in release of greenhouse gases and other pollutants beyond the critical limit which might be influencing this reduction in sunshine hours at Canning.

The region also experienced different degrees of meteorological drought. Meteorological drought years were 
classified on the basis of weekly water requirement (55 mm) for rice cultivation. It was calculated by taking the cumulative weekly rainfall for 22 to 40 standard meteorological weeks (Choudhury et al., 2012). The maximum rainfall of $645.8 \mathrm{~mm}$ in a single meteorological week was received during $39^{\text {th }}$ standard meteorological week in 1986. The years 1982, 1986, 1996, 2006 and 2009 received $<55 \mathrm{~mm}$ rainfall for $>4$ consecutive weeks (CWs) and have been marked as very severe drought years. Similarly, severe meteorological droughts have been observed in 1972, 1994, 2007, 2008 and 2012 on the basis of 4 CWs with rainfall less than $55 \mathrm{~mm}$. Moderately severe ( $3 \mathrm{CWs}$ ) and severe (2 CWs) meteorological drought events occurred 25 and 15 times respectively during the last 50 years. The frequent occurrence of different degrees of droughts indicates a water shortage situation in the future for rice cultivation though the region receives more than $1800 \mathrm{~mm}$ annual rainfall. The cyclone Aila took place during May 2009, and the same year also experienced a very severe meteorological drought. Hence, there was a great scope of rainwater harvesting in the region.

ICAR-Central Soil Salinity Research Institute has developed few land shaping models for water harvesting to enhance the productivity of low lying degraded land of the region and to tackle the prolonged water logging during monsoon season and increasing water availability during rabi season. Large scale adoption of land shaping maybe a solution to tackle the climate change impact in the region (Mandal, et al., 2019b). About 279 ha of low productive salt affected land in Sundarbans has been converted from mono-cropped to multi-cropped with integrated crop and fish cultivation through implementation of different land shaping techniques (CSSRI, NAIP, 2014). ICAR under NICRA (National Innovations in Climate Resilient Agriculture) project also adopted land shaping and integrated farming system as technological interventions in Sundarbans region to develop climate resilient village (Srinivasarao et al., 2016). Land shaping significantly reduced the salinity level and improved agronomic productivity of land in Sundarbans region. These technological interventions also enhanced farm income, increased cropping intensity and promoted crop diversification.

\section{CONCLUSION}

Mean annual rainfall in Sundarbans is $1821 \mathrm{~mm}$ (2461.3-1030.8 mm). Out of 50 years rainfall data, 36 years received normal, 6 years received deficit and 8 years received excess rainfall. Premonsoon (MAM) rainfall contributes $13.2 \%$ (1-35\%) whereas monsoon (JJAS) and post monsoon (ONDJF) contributes $74.3 \%(53-89 \%)$ and 12.5\% (2-28\%), respectively. Trend analysis of 50 years climate parameters in Sundarbans region showed that out of six parameters (viz. annual rainfall, temperatures, relative humidity, wind speed, sunshine hour and $\mathrm{ET}_{0}$ ), the annual sunshine hour and $\mathrm{ET}_{0}$ exhibited a significant decreasing trend whereas, there was no significant change for other parameters. There was 2.7 times surplus rainfall than $\mathrm{ET}_{0}$ during monsoon months indicating very high scope of water harvesting to tackle water logging during the monsoon season and unavailability of fresh water for irrigation during lean season in Sundarbans region. Large scale adoption of land shaping maybe a solution to tackle the climate change impact in the region. This local observation can be used as manifestation of climate changes occurring at coastal region and the findings of this study can be used for future projection studies as well as regional level planning.

\section{ACKNOWLEDGEMENTS}

We thank the Director, ICAR-Central Soil Salinity Research Institute, Karnal for support. This research was supported by the ICAR-NICRA (National Innovations in Climate Resilient Agriculture). We are thankful to Apu Kumar Naiya and Apu Roy for their help.

\section{REFERENCES}

Allen, R., Pereira, L.A., Raes, D. and Smith, M. (1998). Crop Evapotranspiration. FAO Irrigation and Drainage. Paper no. 56. Food and Agricultural Organization of the United Nations, Rome, Italy, 293 pp.

Choudhury, B.U., Das, A., Ngachan, S.V., Slong, A., Bordoloi, L.J. and Chowdhury, P. (2012). Trend analysis of longterm weather variables in mid-altitude Meghalaya, North- East India. J. Agril. Physics, 12:12-22.

CSSRI, NAIP. (2014). Final Report of NAIP sub-project on Strategies for Sustainable Management of Degraded Coastal Land and Water for Enhancing Livelihood Security of Farming Communities. ICAR-Central Soil Salinity Research Institute, Regional Research Station, (CSSRI, RRS), Canning Town - 743 329, India. p. 104.

Hanumanthappa, M., Ananda, M.R., Sridhara, H.P., Nagesha, L. and Sudhirkkamath, K.V. (2010). Annual 
and seasonal rainfall variability in coastal district of Karnataka. J. Agrometeorol. 12: 266-267.

IPCC. (2007). IPCC (Intergovernmental Panel on Climate Change), Climate Change 2007. Fourth Assessment Report. Cambridge University Press, Cambridge, UK.

Krishna Kumar, K., Kamala, K., Rajagopalan, B., Hoerling, M.P., Eischeid, J.K., Patwardhan, S.K., Srinivasan, G., Goswami, B.N. and Nemani, R. (2011). The once and future pulse of Indian monsoonal climate. Clim. Dynamics, 36(11): 2159-2170.

Mandal, S., Choudhury, B.U., Mandal, M. and Bej, S. (2013). Trend analysis of weather variables in Sagar Island, West Bengal, India: a long-term perspective (1982-2010). Current Sci. 105(7): 947-953.

Mandal, U.K., Maji, B., Mullick, S., Nayak, D.B., Mahanta, K.K. and Raut, S. (2019a). Global climate change and human interferences as risk factors, and their impacts on geomorphological features as well as on farming practices in Sundarbans eco-region. In: Sundarbans a trans-boundary dynamic and disaster-prone ecosystem, Sen, H.S., (ed.), Springer International Publishing AG, Cham, pages 405-437.

Mandal, U.K., Burman, D., Bhardwaj, A.K., Nayak, D.B., Samui, A., Mullick, S., Mahanta, K.K., Lama, T.D., Maji, B., Mandal, S., Raut, S. and Sarangi, S.K. (2019b). Waterlogging and coastal salinity management through land shaping and cropping intensification in climatically vulnerable Indian Sundarbans. Agril. Water Manage. 216: 12-26.
Nakicenovic, N., Alcamo, J., Grubler, A., Riahi, K., Roehrl, R.A., Rogner, H-H, and Victor, N. (2000). Special Report on Emissions Scenarios: A Special Report of Working Group III of the Intergovernmental Panel on Climate Change. Cambridge University Press, Cambridge, UK, P. 599.

Narjary, B., Kumar, S., Kamra, S.K., Bundela, D.S. and Sharma, D.K. (2014). Impact of rainfall variability on groundwater resources and opportunities of artificial recharge structure to reduce its exploitation in fresh groundwater zones of Haryana. Current Sci. 107:13051312.

Prabhakar, A.K., Singh, K.K., and Lohani, A.K. (2018). Regional level long-term rainfall variability assessment using Mann-Kendall test over the Odisha state of India. J. Agrometeorol. 20(2): 164-165.

Sen, P. K. (1968). Estimates of the regression coefficient based on Kendall's tau. J. Amer. Stat. Assoc., 63: 1379-1389.

Srinivasarao, Ch., Gopinath, K.A., Prasad, J.V.N.S., Prasannakumar, and Singh, A.K. (2016) Climate resilient villages for sustainable food security in tropical India: concept, process, technologies, institutions, and impacts. Adv. Agron. 140: 101-214.

WWF-India. (2010). Sundarbans: future imperfect, climate adaptation report, pp.1-29.

Yang, X., Xiaohou, S., Xinyu, M., Minhui, L., Xiuneng, L. and Rongqi, L. (2019) Variability and trend analysis of precipitation during 1961-2015 in southwest Guizhou autonomous prefecture, China. J. Agrometeorol., 21(1): 31-35. 